\title{
Rice field flora and vegetation in the provinces of Valencia and Tarragona
}

\author{
J. L. CARRETERO
}

\begin{abstract}
CARretero, J. L., 1986: Ricefield flora and vegetation in provinces of the Valencia and Tarragona (Spain). Collect. Bot. (Barcelona) 17(1):113-124.

Twenty nine emergent and twenty floating or submerged taxa, were found in the rice fields in Valencia and Tarragona provinces. Eleven of these taxa, all them emergent, are alien or introduced ones. Echinochloa oryzoides and E. oryzicola are the most important in both areas, together with Cyperus difformis and Echinochloa hispidula in Valencia. The remaining thirty eight taxa belong to the native flora. There are predominantly the emergent Scirpus maritimus, Alisma plantago-aquatica, Echinochloa crus-galli and Paspalum distichum; the floating Lemna minor and L. gibba; the submersed Potamogeton nodosus; Zannichellia palustris and Najas minor; and the macroscopical algae Chara vulgaris, Cladophora glomerata, Oedogonium capilliforme, Spirogyra spp., Pithophora oedogonia and Hydrodictyon reticulatum. The flora evolution during the last years is analyzed and the present weed communities are studied. The contribution of the different phytosociological classes to the rice field weed flora is presented.
\end{abstract}

Keywords: flora, vegetation, rice fields, Spain.

\section{Resumen}

CARretero, J. L., 1986: Flora y vegetación de los arrozales de las provincias de Valencia y Tarragona. Collect. Bot. (Barcelona) 17(1): 113-124.

De los 49 táxones registrados (29 emergentes y 20 flotantes o sumergidos) 11 son exóticos introducidos, de los cuales los más importantes son Echinochloa oryzoides y $E$. oryzicola en ambas zonas, además de Cyperus difformis y Echinochloa hispidula en Valencia, y el resto propios de la flora autóctona, predominando Scirpus maritimus, Alisma plantago-aquatica, Echinochloa crus-galli y Paspalum distichum como emergentes, Lemna minor y L. gibba como flotantes, Potamogeton nodosus, Zannichellia palustris y Najas minor como sumergidos y Chara vulgaris, Cladophora glomerata, Oedogonium capilliforme, Spirogyra spp., Pithophora oedogonia e Hydrodictyon reticulatum como algas macroscópicas. Se analiza la evolución experimentada por la flora en los últimos años, además de estudiar las comunidades vegetales presentes y de indicar la importancia de las distintas clases fitosociológicas en su contribución a la flora arvense del cultivo.

Palabras clave: flora, vegetación, arrozales, España.

J. L. CARRetero: Cátedra de Botánica Agrícola. E.T.S. de Ingenieros Agrónomos. Valencia. 


\section{INTRODUCTION}

Practically everything published on invasive plants in the rice fields of the provinces of Valencia (zona of La Albufera) and Tarragona (Ebro delta) refers to a few floristic observations (BORJA, 1950; BALADA \& al., 1977; FERRER \& COMÍN, 1979; BALADA, 1981; MARGALEF MIR, 1981; CARRETERO, 1982; Bolós \& Vigo, 1984; BOIRA \& CARRETERO, 1985), to monographs on the Echinochloa and Ammannia genera (CARRETERO, 1981 and 1983), or to the description of the main weeds (BATALLA, 1970 and 1975). No attention is paid to distribution.

The study of rice field vegetation along the Mediterranean coast of Spain carried out by BoLÒS \& MASCLANS (1955) comprises eleven inventories, only three of which correspond to the Ebro delta (and growth after harvesting) and none to Valencia. My doctoral thesis (CARRETERO, 1972) on the rice growing zone of La Albufera is still unpublished.

It was the fragmentary nature of knowledge about rice field flora and vegetation in the provinces of Valencia and Tarragona that led us to undertake this research, which seeks to make a more detailed study of the distribution, abundance and evolution of the weed flora and plant communities present.

The authors of the names of the cormophytes mentioned are taken from Flora Europaea, except Ammannia robusta Heer \& Regel, Echinochloa hispidula (Retz.) Nees ex Royle and Echinochloa oryzicola (Vasing.) Vasing. The names of algae are taken from the studies by VASCONCELLOS (1956), BOURRELLY (1966) and BOIRA \& CARRETERO (1985).

\section{ECOLOGICAL CONSIDERATIONS}

The areas with which this study is concerned constitute, together with the Guadalquivir marshes (Seville), the foremost rice growing zones in Spain. Rice is also grown in Calasparra (Murcia) and various parts of the provinces of Badajoz, Huesca and Girona, but on a much smaller scale.

Both the Ebro delta and the zone around La Albufera have a thermo-mediterranean bioclimate, with somewhat higher temperatures in Valencia on account of its more southernly location. They form part of the climax area of Querco-Lentiscetum Br.-B1. \& col. 1935 em. A. \& O. Bolòs 1950 of the Oleo-Ceratonion Br.-B1. 1936 em. Rivas-Martínez 1975 alliance.

The rice fields are flooded throughout their cycle, except for about one week in July (know as the aixugó or "drying out") and just before harvesting.

Analysis of ten samples taken from each of the rice growing zones dealt with in this study reveals that the soil generally has a texture in which lime and/or clay are predominant, though some soils are sandy (including Sant Carles - Poble Nou and the eastern part of Els Muntells in Tarragona, and El Saler and El Palmar in Valencia). The $\mathrm{pH}$ is basic $(7,60-8,20)$. The limestone content (total 10-55, active 1,25-15,50, expressed in percentages of $\left.\mathrm{CO}_{3} \mathrm{Ca}\right)$ and proportion of organic material (1,20-4,75\%) are usually high. The proportion of sulphates is generally low $\left(0,06-0,35 \%\right.$ of $\left.\mathrm{SO}_{4} \mathrm{Ca}\right)$, though in some places it is higher $(0,75 \%$ $2 \mathrm{~km}$, north of Poble Nou). The salinity ranges from negligeable to moderate in the La Albufera zone (conductivity $1,25-5,20 \mathrm{mmhos} / \mathrm{cm}$, and SAR $0,50-5,05$, both in saturation extract) and from low to moderate in the Ebro delta (cond. 2,25-5,40 mmhos/cm, and SAR 0,90-4,90). The samples we took showed some plots to be more saline: north of Poble Nou in Tarragona, and north east of Sollana and in El Saler (Luis Vives Parador and towards Pinedo) in Valencia.

The fifteen water samples analyzed in each province produced a slightly basic $\mathrm{pH}$ ( 7 to 8 ) and a low to moderate concentration in sulphates (traces to $0,60 \mathrm{~g} / 1$ of $\mathrm{SO}_{4}{ }^{2}$ ). There is usually some salinity (conductivity between 0,60 and $2,30 \mathrm{mmhos} / \mathrm{cm}$ ) and little chlorine $(0,03-0,20$ $\mathrm{gr} / 1 \mathrm{de} \mathrm{Cl}^{-}$), though in some cases the values are higher. Thus to the north of Poble Nou a 
conductivity of $4,5 \mathrm{mmhos} / \mathrm{cm}$ and $\mathrm{C} \mathrm{Cl}^{-}$concentration of $1,25 \mathrm{~g} / 1$ were measured, while in El Saler, opposite the Parador Luis Vives, the values were 5 and 1,0 respectively.

I observed hardly any clear repercussions on the distribution of the main species present as a result of these variations in the soils and water analysed.

As for agricultural techniques, transplanting has mostly fallen into disuse and direct sowing takes place at the beginning of May. The aixugó last seven to ten days in July and the harvest is at the end of September. Herbicides are in general use, the main products being molinato (applied before the seedlings come up), or propanil (applied at the beginning of the cycle on seedlings with two to four leaves against Echinochloa spp.) and bentazon (during the aixugó mainly against Alisma plantago-aquatica and Cyperaceae). Hand weeding is also frequent and crops are very often treated with algicides a few days after sowing.

\section{FLORA}

The study was conducted during the summer of 1984. In order to determine the distribution and abundance of the weeds, I selected a hundred weed-ridden fields in each of the two provinces studied for emergent as well as floating and submerged flora. These fields were scattered throughout both the rice-growing areas. In each site an inventory of an area of $100 \mathrm{~m}^{2}$ was compiled; the species present were listed and the number of $1 \mathrm{~m}^{2}$ squares in which each species was found was specified.

Tables 1 and 2 show the presence (number of inventories in which the species is present), the degree of presence or constancy (proportion of inventories where the species grows: $\mathrm{R}<$ $5 \%, \mathrm{I}=5-20 \%, \mathrm{II}^{\prime} 21-40 \%, \mathrm{III}=41-60 \%, \mathrm{IV}=61-80 \%, \mathrm{~V}=81-100 \%$ ), overall frequency (percentage of $1 \mathrm{~m}^{2}$ squares in which the species is present out of all the squares in all the inventories) and partial frequency (percentage of squares in which the species is present out of all the squares belonging to those inventories containing the species).

\section{Emergent flora}

The sample was taken between mid-July and the end of August, when all the species (especially those belonging to the Echinochloa genus) had flowered and identification posed no problems.

In Table 1 we see a list of 28 taxa for the La Albufera zone and 22 for the Ebro delta. By eliminating those with a very low degree of presence (R), one obtains 16 and 10 species respectively. Though the rice fields of Valencia contain more species, the floristic composition of the emergent vegetation is similar in the two zones.

In the rice fields of La Albufera, the main weeds in decreasing order of overall frequency with a score over $8 \%$ are: Alisma plantago-aquatica, Scirpus maritimus, Echinochloa oryzoides, Cyperus difformis, Echinochloa hispidula, Paspalum distichum, Echinochloa oryzicola and Echinochloa crus-galli. In the Ebro delta they are: Echinochloa oryzicola, Echinochloa oryzoides, Scirpus maritimus, Paspalum distichum and Echinochloa crus-galli. The most significant differences are the low frequency of Alisma plantago-aquatica, Cyperus difformis and Echinochloa hispidula in the province of Tarragona and the lesser importance of Echinochloa oryzicola and Echinochloa oryzoides in Valencia.

Species with lower constancy $(<25 \%)$ and low overall frequency $(<8 \%)$, Typha angustifolia (including subsp. australis), Bergia capensis, Ammannia robusta, Scirpus supinus, Scirpus mucronatus, Ammannia coccinea and Lindernia dubia are more plentiful in the La Albufera area than in the Ebro delta.

Though presence and frequency values may vary from year to year, according to enviromental conditions and the effectiveness of herbicides, the figures in Table 1 provide a good 
Table 1. - Emergent rice field flora in the provinces of Valencia (V) and Tarragona (T). $\mathrm{n}=100$

\begin{tabular}{|c|c|c|c|c|c|c|c|c|}
\hline \multirow[b]{2}{*}{ Characteristic species } & \multicolumn{2}{|c|}{$\begin{array}{l}\text { Presence } \\
\text { (constancy) }\end{array}$} & \multicolumn{2}{|c|}{$\begin{array}{l}\text { Degree of } \\
\text { presence }\end{array}$} & \multicolumn{2}{|c|}{$\begin{array}{l}\text { Overall } \\
\text { frequency }\end{array}$} & \multicolumn{2}{|c|}{$\begin{array}{c}\text { Partial } \\
\text { frequency }\end{array}$} \\
\hline & (V) & (T) & (V) & $(\mathrm{T})$ & $(\mathrm{V})$ & (T) & (V) & (T) \\
\hline Echinochloa oryzoides & 54 & 68 & III & IV & $20{ }^{\prime} 60$ & $38^{\prime} 00$ & $38 ’ 15$ & $55^{\prime} 88$ \\
\hline Echinochloa oryzicola & 32 & 84 & II & V & $11 ' 21$ & $55^{\prime} 21$ & $35^{\prime} 03$ & 6573 \\
\hline Cyperus difformis & 47 & 6 & III & I & $20 ; 32$ & 2'15 & $43^{\prime} 23$ & $35 ' 83$ \\
\hline Echinochloa hispidula & 46 & 2 & III & $\mathrm{R}$ & $18^{\prime} 48$ & $0 ’ 20$ & $40 ' 17$ & $10 ’ 00$ \\
\hline Bergia capensis & 23 & 3 & II & $\mathrm{R}$ & $6 ' 33$ & 0'41 & $27 ' 52$ & $13^{\prime} 67$ \\
\hline Ammannia robusta & 20 & 4 & I & $\mathrm{R}$ & 4'79 & $0{ }^{\prime} 22$ & $23 ’ 95$ & 5,50 \\
\hline Ammannia coccinea & 13 & 2 & I & $\mathrm{R}$ & $2^{\prime} 38$ & $0 ' 12$ & $18^{\prime} 31$ & $6{ }^{\prime} 00$ \\
\hline Lindernia dubia & 10 & 1 & I & $\mathrm{R}$ & $1^{\prime} 00$ & $0 ’ 03$ & $10 ’ 00$ & $3 ’ 00$ \\
\hline Ammannia aegyptiaca & 1 & - & $\mathrm{R}$ & - & $0 ’ 08$ & - & $8^{\prime} 00$ & - \\
\hline
\end{tabular}

Phragmitetea

Scirpus maritimus

Alisma plantago-aquatica

$\begin{array}{rr}64 & 62 \\ 66 & 22 \\ 23 & 10 \\ 17 & 6 \\ 2 & 7 \\ 2 & 2 \\ 2 & 1 \\ 1 & - \\ 1 & - \\ 1 & -\end{array}$

IV IV

IV II

II

I $\quad 3$ '89

$\begin{array}{lll}\mathrm{R} & \mathrm{I} & 0 \\ \mathrm{R} & 08\end{array}$

$\begin{array}{lll}\mathrm{R} & \mathrm{R} & 0 \\ \mathrm{R} & \mathrm{R} 8\end{array}$

R $\quad \mathrm{R} \quad 00^{\prime} 09$

$\mathrm{R}$ - 0,05

$\begin{array}{lll}\mathrm{R} & - & 0 \\ \mathrm{R} & - & 02\end{array}$

$\mathrm{R} \quad-\quad 0^{\prime} 02$

\section{0 '05}

6'23

2'82

0'84

0'62

0 '09

0 '02

$-$

$45 ' 17$

48 '21

29 '13

22' 88

4'00

$4^{\prime} 00$

4'50

5,00

- $\quad 2$ '00

$-\quad 2^{\prime} 00$ $48^{\prime} 47$

$28 \times 32$

$28 ' 20$

14 '00

$8^{\prime} 86$

4'50

2'00

$-$

$-$

Veronica anagallis-aquatica

\section{Bidentetea}

Echinochloa crus-gallit ${ }^{(1)}$

Paspalum distichum ${ }^{(1)}$

Eclipta prostrata

Polypogon monspeliensis

Polygonum lapathifolium

Ranunculus sceleratus

Isoeto-Nanojuncetea

Scirpus supinus

Cyperus fuscus

$\begin{array}{rr}39 & 32 \\ 34 & 29 \\ 6 & 2 \\ 3 & 1 \\ 1 & - \\ - & 1\end{array}$

II
II
I
R
R
-

$\begin{array}{cr}\text { II } & 11^{\prime} 12 \\ \text { II } & 11^{\prime} 30 \\ \mathrm{R} & 0{ }^{\prime} 36 \\ \mathrm{R} & 0^{\prime} 06 \\ \mathrm{C} & 0^{\prime} 04 \\ \mathrm{R} & -\end{array}$

$\begin{array}{crc}8^{\prime} 37 & 28^{\prime} 51 & 26^{\prime} 16 \\ 9^{\prime} 31 & 33^{\prime} 23 & 32^{\prime} 10 \\ 0^{\prime} 04 & 6^{\prime} 00 & 2^{\prime} 00 \\ 0^{\prime} 03 & 2^{\prime} 00 & 3^{\prime} 00 \\ - & 4^{\prime} 00 & - \\ 0^{\prime} 02 & - & 2^{\prime} 0\end{array}$

$19 \quad 1$

$\begin{array}{lll}\mathrm{I} & \mathrm{R} & 4,32 \\ \mathrm{R} & \mathrm{R} & 0,02\end{array}$

0’05

22'74

$5 ’ 00$

0'10 2'00 5'00

Plantaginetea

Panicum repens

Rumex conglomeratus

\begin{tabular}{|c|c|c|c|c|c|c|c|}
\hline 2 & - & $\mathrm{R}$ & - & $0^{\prime} 07$ & - & 3'50 & - \\
\hline 1 & - & $\mathrm{R}$ & - & $0^{\prime} 03$ & - & $3^{\prime} 00$ & - \\
\hline
\end{tabular}

(1) Could also be considered to belong to Panico-Setarion and Plantaginetea respectily.

picture of the distribution and abundance of emergent weeds in the rice fields of the provinces of Valencia and Tarragona. There may also be some variation according to the period of the rice cycle in which the sample is taken: for instance, the proportion of Alisma plantagoaquatica and Scirpus maritimus is usually greater before the fields are subjected to the aixugó. 
Some species recorded in earlier studies, albeit on a very small scale, were not found in the rice fields on this occasion. These include Ludwigia uruguayensis (TORRES, 1968:1160) and Cyperus serotinus, Samolus valerandi and Chenopodium glaucum (Bolòs \& MASCLANS, 1955: 418-419, in already harvested fields) in the Ebro delta, and Aster squamatus and Ranunculus sceleratus (CARRETERO, 1972) in La Albufera.

\section{Floating and submerged flora}

The sample, much of which comes from different sites from the emergent flora, was taken between mid-June (well-developed floating and submerged vegetation) and mid-August (when in some fields the rice is not yet too thick).

Table 2. - Floating and submerged rice field flora in the provinces of Valencia (V) and Tarragona (T). $\mathrm{n}=100$

\begin{tabular}{|c|c|c|c|c|c|c|c|c|}
\hline & \multicolumn{2}{|c|}{$\begin{array}{l}\text { Presence } \\
\text { (constancy) }\end{array}$} & \multicolumn{2}{|c|}{$\begin{array}{l}\text { Degree of } \\
\text { presence }\end{array}$} & \multicolumn{2}{|c|}{$\begin{array}{l}\text { Overall } \\
\text { frequency }\end{array}$} & \multicolumn{2}{|c|}{$\begin{array}{c}\text { Partial } \\
\text { frequency }\end{array}$} \\
\hline & (V) & (T) & (V) & $(\mathrm{T})$ & $(\mathrm{V})$ & $(\mathrm{T})$ & (V) & $(\mathrm{T})$ \\
\hline \multicolumn{9}{|l|}{ Lemnetea } \\
\hline Lemna minor & 62 & 64 & IV & IV & $41^{\prime} 05$ & $45^{\prime} 55$ & $66 ' 21$ & $71 ' 77$ \\
\hline Lemna gibba & 42 & 41 & III & III & $26{ }^{\prime} 90$ & $26 ’ 01$ & $64 ’ 05$ & $63^{\prime} 44$ \\
\hline \multicolumn{9}{|l|}{ Potametea } \\
\hline Potamogeton nodosus & 35 & 30 & II & II & $13^{\prime} 38$ & $10 ’ 50$ & $38 ’ 23$ & $355^{\prime} 00$ \\
\hline Zannichellia palustris s.l. & 29 & 25 & II & II & $16^{\prime} 00$ & $12^{\prime} 63$ & $55^{\prime} 17$ & $50 ' 52$ \\
\hline Najas minor & 7 & 44 & I & III & $2 ’ 35$ & $25^{\prime} 62$ & $33 ’ 57$ & $58 ' 23$ \\
\hline Marsilea quadrifolia & 1 & - & $\mathrm{R}$ & - & $0 ' 12$ & - & $12^{\prime} 00$ & - \\
\hline \multicolumn{9}{|l|}{ Ceratophylletea } \\
\hline Ceratophyllum demersum & 3 & 12 & $\mathrm{R}$ & I & $0 ’ 82$ & 7'58 & $27 ’ 33$ & $63 ’ 17$ \\
\hline \multicolumn{9}{|l|}{ Utricularietea } \\
\hline Utricularia vulgaris & 1 & - & $\mathrm{R}$ & - & 0’18 & - & $18^{\prime} 00$ & - \\
\hline \multicolumn{9}{|l|}{ Charetea } \\
\hline Chara vulgaris & 33 & 52 & II & III & 13 '82 & $36 ’ 65$ & $41 ' 89$ & $70 ’ 48$ \\
\hline Chara braunii & 3 & 7 & $\mathrm{R}$ & I & $0 ’ 80$ & 3'64 & $26 ’ 67$ & $52^{\prime} 00$ \\
\hline Chara globularis & 2 & - & $\mathrm{R}$ & - & $0 ’ 25$ & - & $12 ’ 50$ & - \\
\hline \multicolumn{9}{|l|}{$\begin{array}{l}\text { Filamentous, reticular } \\
\text { and laminarian algae }\end{array}$} \\
\hline Cladophora glomerata & 36 & 42 & II & III & $14 ' 58$ & $16 ' 52$ & 40 '50 & $39 ’ 33$ \\
\hline Oedogonium capilliforme & 31 & 41 & II & III & $11^{\prime} 42$ & $15^{\prime} 77$ & $36^{\prime} 84$ & $38^{\prime} 46$ \\
\hline Spirogyra spp. & 18 & 26 & I & II & $3 ’ 80$ & 5,33 & $21 ' 11$ & $20 ' 50$ \\
\hline Pithophora oedogonia & 15 & 23 & I & II & $4^{\prime} 65$ & $7 ' 28$ & $31^{\prime} 00$ & $31^{\prime} 65$ \\
\hline Hydrodictyon recticulatum & 11 & 22 & I & II & $1 ' 83$ & 5,82 & $16^{\prime} 64$ & $26^{\prime} 45$ \\
\hline Enteromorpha intestinalis & 4 & 5 & $\mathrm{R}$ & I & 0 '62 & $0 ’ 80$ & $15{ }^{\prime} 50$ & $16^{\prime} 00$ \\
\hline Cladophora fracta & - & 8 & - & I & - & $1 ' 85$ & - & 23 '13 \\
\hline Zygnema sp. & - & 3 & - & $\mathrm{R}$ & - & 0,50 & - & $16^{\prime} 67$ \\
\hline Monostroma oxyococcus & 1 & - & $\mathrm{R}$ & - & $0 ’ 06$ & - & $6 ’ 00$ & - \\
\hline
\end{tabular}


Table 2 contains a list of eight vascular taxa and ten macroscopic algae for the province of Valencia and six and ten respectively for the province of Tarragona. Though the floristic composition is similar in the two rice growing zones, floating and submerged vegetation is more plentiful in the Ebro delta.

Predominant vascular plants, in decreasing order of overall frequency, are: Lemna minor, Lemna gibba, Zannichellia palustris* and Potamogeton nodosus in the La Albufera zone, and the same species, but with Najas minor in third position, in the Ebro delta. Species not found in the samples but reported in the literature are Marsilea quadrifolia in Tarragona (BALADA, 1981: 6) and Callitriche stagnalis and Ranunculus baudotii in Valencia (CARRETERO, 1972).

Of the algae, Cladophora glomerata, Chara vulgaris, Oedogonium capilliforme, Spirogyra spp., Pithophora oedogonia and Hydrodictyon reticulatum are those with the greatest presence and frequency in both rice-growing zones. I have no references of any earlier report of Chara braunii in the Ebro delta: it was found in Sant Jaume, between Jesús i Maria and Amposta, in grid squares $\mathrm{CF} 00$ and $\mathrm{CF} 01$.

\section{Evolution of the flora}

Progress in agricultural techniques over the last few years, especially direct sowing and widespread use of herbicides, has led to certain changes in arvicolous flora in the rice fields in both zones under study. While the species present remain virtually unchanged, there have been substantial changes in the extent to which many are present.

Though most of the eleven inventories by BoLòs \& MASCLANS (1955) come from the provinces of Barcelona and Girona, and only three from the Ebro delta, they can be used to draw at least approximate comparisons with the present inventory, as far as emergent flora is concerned (Table 1). A sharp drop is observed in characteristic (exotic) species with broad leaves (Ammannia coccinea, Bergia capensis and Lindernia dubia) and in Cyperus difformis. In contrast, species belonging to Echinochloa have increased. The most striking changes in the accompanying taxa, are the decline of Alisma plantago-aquatica and the greater profusion of Scirpus maritimus, which is now one of the commonest weeds.

Comparison of the inventories drawn up in Valencia in 1970 and 1971 (CARRETERO, 1972) with those in Table 1, shows, that Ammannia coccinea and Bergia capensis have declined but less than in Tarragona. The presence of Cyperus difformis remains about the same. In the Echinochloa genus, E. oryzoides and E. hispidula are more plentiful, to the detriment of $E$. oryzicola. Among accompanying species, Alisma plantago-aquatica is as widespread as before while Scirpus maritimus and Typha angustifolia have increased considerably.

\section{VEGETATION}

Information provided by the sample taken for the study of the flora also served for the analysis of the vegetation, Braun-Blanquet's phytosociological methodology was followed.

\section{Emergent vegetation}

While awaiting the conclusions of a comparative study of rice field vegetation in Western Europe which is shortly to appear, we continue for the time being to consider that the emergent vegetation corresponds to the association Cypero-Ammannietum coccineae O. Bolòs \& F. Masclans 1955.

\footnotetext{
*Note: We have included in Zannichiella palustris another species of Zannichiella, Z. peltata and Z. pendunculata In fact, most of specimens studied must correspond to the two later.
} 
Table 3. - Percentage of the sums of presences and overall frequencies of each phytosociological group

\begin{tabular}{|c|c|c|c|c|c|c|c|c|}
\hline & \multicolumn{4}{|c|}{$\%$ of the sum of presences } & \multicolumn{4}{|c|}{$\%$ of the sum of overall frecuencies } \\
\hline & (V) & $(\mathrm{T})$ & (V) & $(\mathrm{T})$ & $(\mathrm{V})$ & $(\mathrm{T})$ & (V) & $(\mathrm{T})$ \\
\hline Emergent vegetation & \multicolumn{2}{|c|}{ (1) } & \multicolumn{2}{|c|}{ (3) } & \multicolumn{2}{|c|}{ (1) } & \multicolumn{2}{|c|}{ (3) } \\
\hline Oryzetea & $46^{\prime} 33$ & $48 ’ 85$ & $28^{\prime} 44$ & $21 ' 44$ & $46{ }^{\prime} 26$ & $62 ' 18$ & $24{ }^{\prime} 57$ & $25{ }^{\prime} 62$ \\
\hline Phragmitetea & $33 ’ 71$ & $31 ' 61$ & $20{ }^{\prime} 69$ & 13 '87 & $38^{\prime} 91$ & $26{ }^{\prime} 25$ & $200^{\prime} 66$ & $100^{\prime} 82$ \\
\hline Bidentetea & $15^{\prime} 63$ & $18^{\prime} 68$ & 9'60 & $8 ’ 20$ & $12 ’ 42$ & 11 '47 & 6'60 & 473 \\
\hline Isoeto-Nanojuncetea & 3’77 & $0 ’ 86$ & 2'31 & $0 ’ 38$ & $2 ’ 36$ & $0 ’ 10$ & 1225 & $0 ’ 04$ \\
\hline Plantaginetea & $0 ’ 56$ & - & $0 ’ 35$ & - & 0 ’05 & - & $0 ’ 03$ & - \\
\hline $\begin{array}{l}\text { Floating and sumerged } \\
\text { vegetation }\end{array}$ & \multicolumn{2}{|c|}{ (2) } & $61 ’ 39$ & $\begin{array}{l}43 \text { '89 } \\
\text { (3) }\end{array}$ & 100 & 100 & 53’11 & 41'21 \\
\hline Lemnetea & $31 ' 14$ & $23 ' 60$ & $12^{\prime} 02$ & $13 \cdot 24$ & $41^{\prime} 78$ & $32 ’ 37$ & $19 ’ 59$ & $19^{\prime} 03$ \\
\hline Potametea & $21 ’ 55$ & $22 ’ 24$ & $8^{\prime} 32$ & $12^{\prime} 48$ & $19 ' 59$ & $222^{\prime} 05$ & 9'18 & $12^{\prime} 97$ \\
\hline Ceratophylletea & $0 ’ 90$ & 2’70 & $0 ’ 35$ & 1'51 & $0 ’ 50$ & 3’43 & $0 ’ 24$ & $2^{\prime} 02$ \\
\hline Utricularietea & $0 ’ 30$ & - & 0 '12 & - & $0 ’ 11$ & - & $0 ’ 05$ & - \\
\hline Charetea & $11 ’ 38$ & $13 ’ 26$ & 4'39 & $7 ' 44$ & $15 ' 29$ & $18^{\prime} 23$ & $7 ' 17$ & $10 ’ 71$ \\
\hline \multirow[t]{2}{*}{$\begin{array}{l}\text { Filamentous, reticular } \\
\text { and laminarian algae }\end{array}$} & 3473 & $38 ' 20$ & $13 ’ 41$ & $21 ’ 44$ & $222^{\prime} 73$ & $23{ }^{\prime} 92$ & $10 ’ 66$ & $14 ’ 06$ \\
\hline & 100 & 100 & $38 ' 61$ & $56 ’ 11$ & 100 & 100 & $46 \% 89$ & 5879 \\
\hline
\end{tabular}

(1) With respect to emergent vegetation.

(2) With respect to floating and submerged vegetation.

(3) With respect to all vegetation.

The characteristic taxa are exotic therophytes. Some are of American origin (Ammannia coccinea, Ammannia robusta and Lindernia dubia), others of Asiatic origin (Echinochloa oryzoides, E. oryzicola, E. hispidula and Cyperus difformis) and still others are of Afro-Asiatic origin (Bergia capensis and Ammannia aegyptiaca). In our latitudes they reach optimum development in the aquatic biotope of ricefields. As can been seen in Table 3, these species constitute the largest and most widespread group of weeds in the rice fields of both zones, especially in Tarragona, where the presence and frequency of Echinochloa oryzicola and E. oryzoides are particularly marked.

The accompanying flora (except Ludwigia uruguayensis and Eclipta prostrata, whose presence is slight) is made up of autochtonous cormophytes found in flooded or muddy stations. The commonest plants in this group are the generally hardy Phragmitetea $\mathrm{R}$. Tx. \& Preising 1942, especially Scirpus maritimus and Alisma plantago-aquatica. The fact that the latter species is less frequent in Tarragona causes the percentage of overall frequency of the Phragmitetea class to be substantially lower in this province than in Valencia.

Of the other accompanying species (belonging to Bidentetea tripartiti R. Tx., Lohmeyer \& Preising 1950, Isoeto-Nanojuncetea Br.-Bl. \& R.Tx. 1943 or Plantaginetea majoris R. Tx. \& Preising 1950), Echinochloa crus-galli and Paspalum distichum (and Scirpus supinus in Valencia) are the most frequently represented.

\section{Floating and submerged vegetation}

This consists mainly of autochtonous plants which invade the $10-30 \mathrm{~cm}$ of water covering the bottom part of the crop: cormophytes belonging to Lemnetea, Potametea, Ceratophylletea, 
and, occasionally, Utricularietea, as well as talophytes belonging to Charetea and various communities of reticular or laminarian filamentous algae. The importance of each group (in terms of percentages of presence and overall frequency) is indicated in Table 3.

Since the submerged species characteristic of different syntaxa usually intermingle, it is impossible to decide to which plant community many of the species documented should be attributed. Nevertheless there are many which, on account of the great predominance of some of the taxa, can perfectly well be included in associations already described.

Table 4 (the degree of presence of the species is reflected much more clearly in Tables 1 and 2) has been compiled from those inventories which reveal the presence among floating and submerged vegetation of the following associations (in addition to the main emergent vegetation):

\section{Lemnetum gibbae}

Community of floating cormophytes (acropleustophyts of the aepipleon), very common throughout the Iberian Peninsula and plentiful in the rice fields of the two zones under study. Lemna gibba is found as a characteristic species, accompanied by Lemna minor, and its presence is accentuated by the fact that the aquatic medium in many of the fields is not too eutrophic.

\section{Potametum denso-nodosi}

Community of rooted cormophytes made up of magnopotamyds belonging to the genera Potamogeton (P. nodosus, P. pectinatus, P. pusillus, P. cripsus), Groenlandia (G. densa) and Myriophyllum (M. spicatum and M. verticillatum). Very widespread in irrigation channels in Catalonia and the Valencian Country.

In the rice fields of the provinces of Valencia and Tarragona this community is much impoverished, consisting only of Potamogeton nodosus which, though it sometimes manages to cover the entire surface of the water, is usually confined to small areas.

\section{Parvopotamo - Zannichellietum tenuis}

Vegetation belonging to Zannichellia palustris s.l. (an annual parvopotamyd cormophyte which roots in the sediment/silt), found in shallow alcaline, mineralized fresh or slightly salt waters and sometimes in polluted water.

It is plentiful in the rice fields of the zone under study, especially in the first phases of the crop cycle, when it forms a sometimes continuous blanket layer at the bottom of the water.

\section{Najadetum minoris}

Community made up of Najas minor, a species similar in appearance and behaviour to Zannichellia palustris, but less widespread in the Iberian Peninsula.

In the Valencian rice fields Najas minor is somewhat uncommon and is always accompanied by other plant groups. In the Ebro delta it is plentiful, forming sufficiently large masses to constitute a plant association.

\section{Ceratophylletum demersi}

Community of submerged un-rooted cormophytes (mesopleuston) consisting exclusively of Ceratophyllum demersum as a characteristic species, accompanied by taxa belonging to Potametea.

This association, which is pollution-resistant and is plentiful in irrigation ditches in rice growing areas, is uncommon inside rice fields, especially in the province of Valencia where it is extraordinarily fragmented.

\section{Community of Utricularia vulgaris}

Inventory No. 16 in Table 4, which was compiled between La Meta dels Sants and El Perelló (Sueca, Valencia), may be assimilated to the formations of Utricularia vulgaris (a 


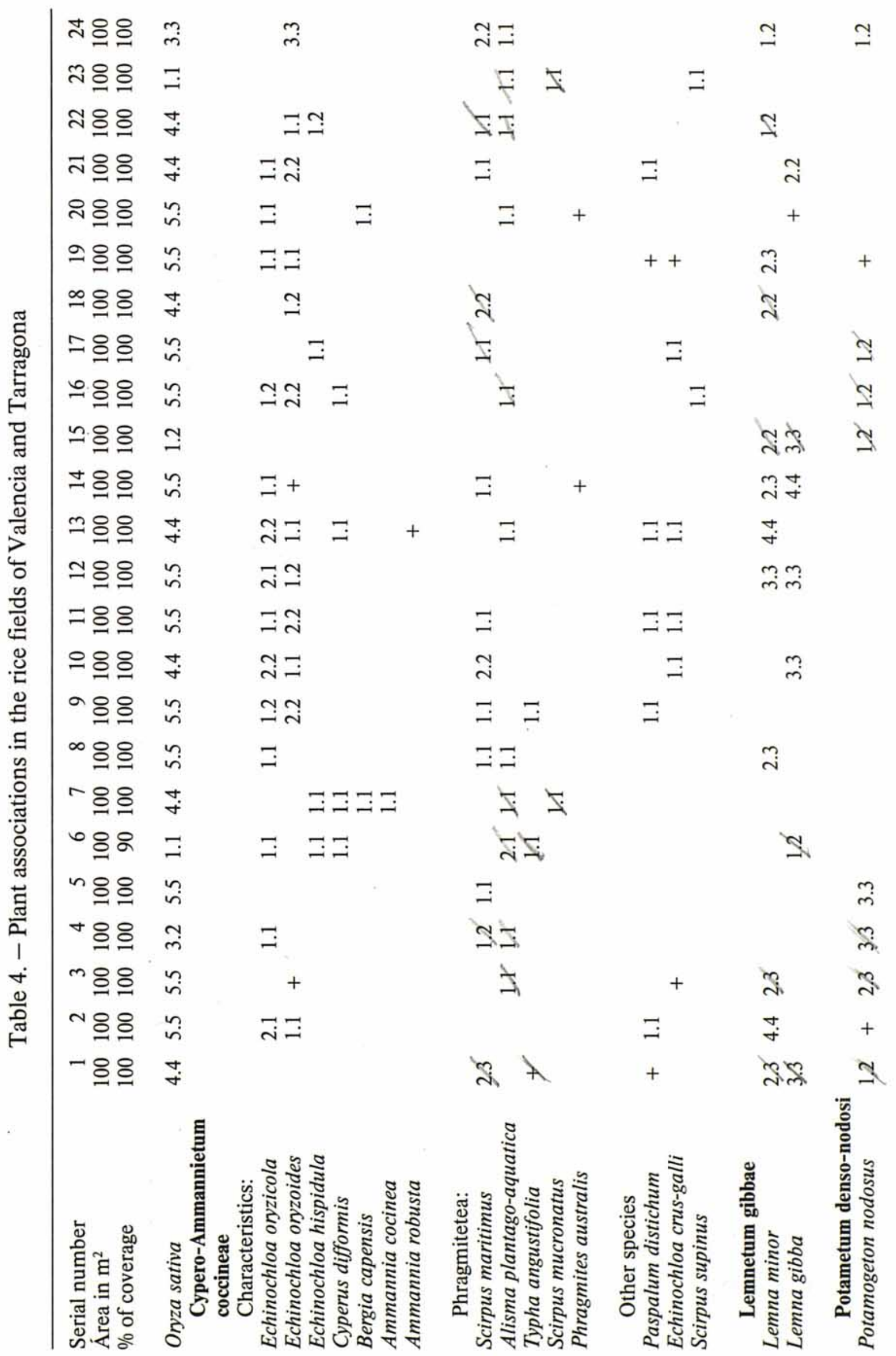




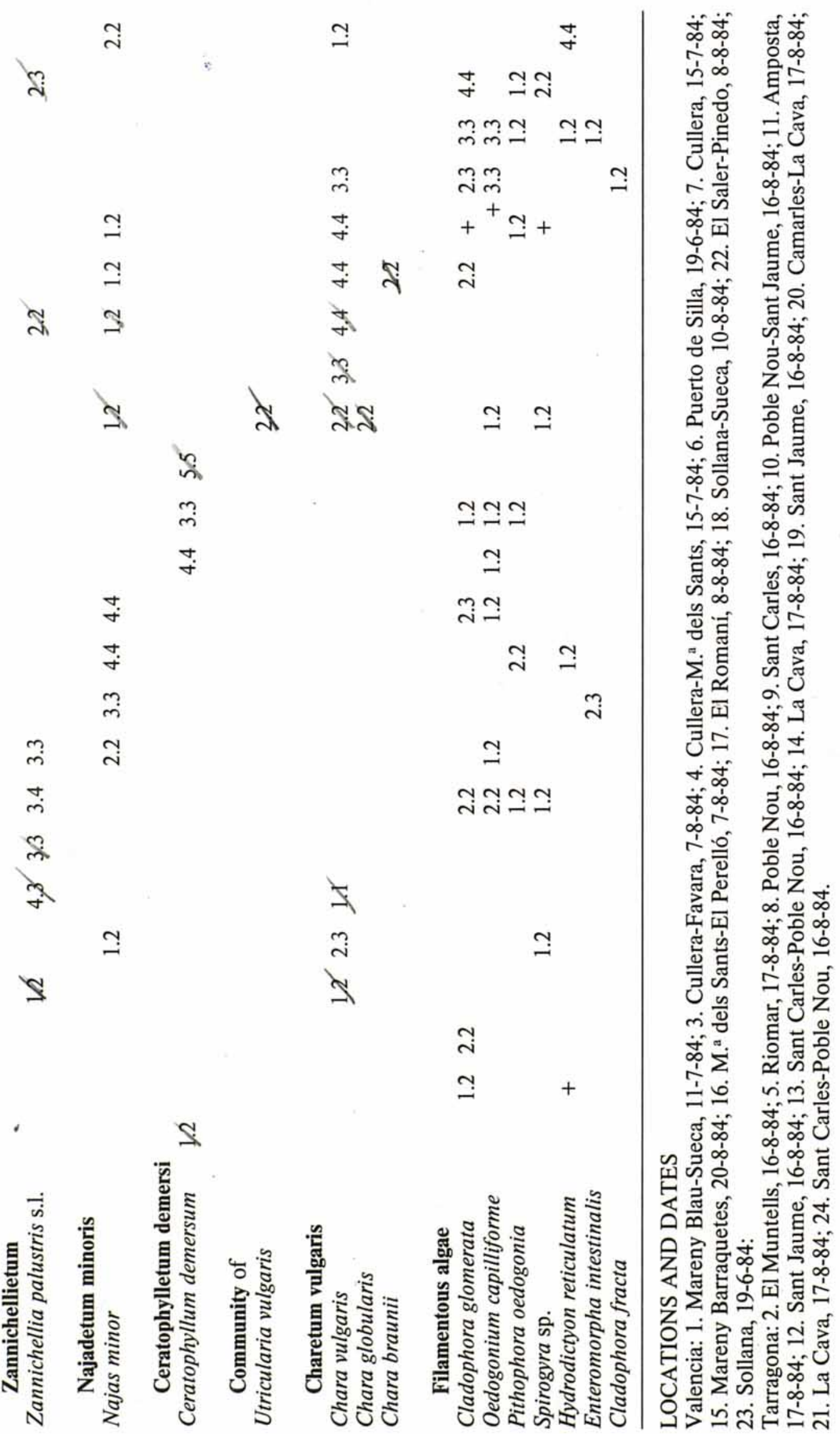


mesopleustophyte with trophic vesicles and emergent flowers) described by CoSTA \& al. (1986) in the bogs of Xeresa (Valencia) and Nules (Castellón).

\section{Charetum vulgaris}

In the rice fields of Valencia and Tarragona, this association made up of carophytes (specially Chara vulgaris) occupies an ecological slot similar to Parvopotamo-Zannichellietum tenuis and Najadetum minoris (totally submerged, little developed therophytic rooted vegetation) with which it frequently mingles. It is somewhat sensitive to water pollution.

Filamentous, reticular or laminarian algae

These usually constitute intermingled communities, the most representative of which in both areas is Cladophoretum glomeratae while Hydrodictyetum reticulati is fragmentary in Valencia but more widespread in Tarragona. In addition to the species from which these associations take their names, Oedogonium capilliforme, Spirogyra spp. p. and Pithophora oedogonia are also plentiful. At the beginning of the crop cycle, prior to the period when the samples were taken, Rhyzoclonium hieroglyphicum is found in some fields that are not treated with algicides. The Vaucherietum found in Italian rice fields (PIGNATTI, 1957; CIFERRI, 1960) can be observed, at least in Valencia, in fields that remain flooded after the rice is harvested.

\section{BIBLIOGRAPHY}

Balada, R. (1981). Nova aportació al coneixement de la flora del delta de l'Ebre. Fol. Bot. Misc., 2:5-7. BaladA, R. \& al. (1977). Catàleg florístic del delta de l'Ebre. Treb. Inst. Cat. Hist. Nat. 8:69-101.

Batalla, J. A. (1970). Las malas hierbas del arrozal y los herbicidas para combatirlas. Fed. Sind. Agríc. Arroceros España. Valencia.

Batalla, J. A. (1975). Las algas de los arrozales y el empleo de los alguicidas. Fed. Sind. Agríc. Arroceros España. Valencia.

Boira, H. \& J. L. CARRETERo (1985). Las caroficeas de las provincias de Castellón y Valencia. Collect. Bot. (Barcelona) 16(1):13-19.

Bolós, O. DE \& F. MASCLANS (1955). La vegetación de los arrozales en la región mediterránea. Collect. Bot. (Barcelona) 4(3):415-434.

Bolòs, O. DE J. VIGO (1984). Flora dels països catalans. Vol. 1: Licopodiàcies-Capparàcies. Barcelona.

BorJa, J. (1950). Estudio fitográfico de la Sierra de Corbera (Valencia). Anales Jard. Bot. Madrid 9:361-483.

Bourrelly, P. (1966). Les Algues d'eau douce. 1: Les Algues Vertes. Paris.

CARRETERO, J. L. (1972). Estudio descriptivo y fitosociológico de la vegetación espontánea fanerógama en la zona arrocera de La Albufera de Valencia. Tesis Doctoral, E.T.S.I.A. Valencia.

Carretero, J. L. (1981). El género Echinochloa Beauv. en el suroeste de Europa. Anales Jard. Bot. Madrid, 38(1):91-108.

CARRETERO, J. L. (1982). Algunas plantas interesantes de la zona arrocera valenciana. Anales Jard. Bot. Madrid, 39(1):215-216.

CArretero, J. L. (1983). El género Ammannia L. (Lythraceae) en España. Anales Jard. Bot. Madrid, 39(2):273-277.

CifERri, R. (1960). Le associazioni di alghe filamentose delle risaie pavese e la loro evoluzione. Att. Ist. Bot. Lab. Critt. Univ. Pavia, ser. 5,18:270-281.

CostA, M. \& al., (1986). La vegetación acuática y palustre valenciana. Ecologia Medit. 12(1-2):83-100.

FERrer, X. \& F. A. Comín (1979). Distribució i ecologia dels macròfits submergits del delta de l'Ebre. Butll. Inst. Cat. Hist. Nat., 44 (sec. Bot., 3):111-117.

Margalef Mir, R. (1981). Distribución de los macrófitos de las aguas dulces y salobres del E y NE de España y dependencia de la composición química del medio. Fundación J. March. Madrid.

Pignatti, S. (1957). La vegetazione delle risaie pavesi. Arch. Bot. Biogreogr. Ital., 33,4ª ser., 2(1-2):129-193.

TORRES, L. DE (1968). Algunas especies interesantes recolectadas en el delta del Ebro y en el Montsià. Collect. Bot. (Barcelona) 7(2):1159-1161.

Vasconcellos, J. C. (1956). Algas macroscopias dos arrozais portugueses. Com. Reg. Com. Arroz. Lisboa. 


\section{SYNTAXONOMIC OUTLINE}

Cl. Oryzetea sativae Miyawaki 1960.

Ord. Cypero-Echinochloetalia oryzoidis O. Bolòs \& Masclans 1955.

Al. Oryzo-Echinochloion oryzoidis O. Bolòs \& Masclans 1955.

Ass. Cypero-Ammannietum difformis O. Bolòs \& F. Masclans 1955.

Cl. Lemnetea minoris W. Koch \& R. Tx. in R. Tx. 1955.

Ord. Lemnetalia minoris W. Koch \& R. Tx. in R. Tx. 1955.

Al. Lemnion gibbae R. Tx. \& Schwabe in R. Tx. 1974.

Ass. Lemnetum gibbae (W. Koch, 1954) Miyawaki \& R. Tx. 1960.

Cl. Potametea R. Tx. \& Preising 1942 em. Den Hartog \& Segal 1964.

Ord. Magnopotametalia (W. Koch 1926) Den Hartog \& Segal 1964.

Al. Magnopotamion (W. Koch 1926) Den Hartog \& Segal 1964.

Ass. Potametum denso-nodosi O. Bolòs 1957.

Ord. Parvopotametalia Den Hartog \& Segal 1964.

Al. Parvopotamion Vollmar 1947.

Ass. Parvopotamo-Zannichellietum tenuis W. Koch 1926.

Ass. Najadetum minoris Ubrizsy 1948.

Cl. Ceratophylletea Den Hartog \& Segal 1964.

Ord. Ceratophylletalia Den Hartog \& Segal 1964.

Al. Ceratophyllion Den Hartog \& Segal 1964.

Ass. Ceratophylletum demersi (Hild 1956) Den Hartog \& Segal 1964.

Cl. Utricularietea intermedio-minoris Den Hartog \& Segal 1974 em. Pietsch 1965.

Ord. Utricularietalia intermedio-minoris Pietsch 1965.

Al. Sphagno-Utricularion Th. Müller \& Görs 1960.

Community of Utricularia vulgaris.

Cl. Charetea Fukarek 1961.

Ord. Charetalia Sauer 1937.

Al. Charion fragilis Rübel 1933 em. Krausch 1964.

Ass. Charetum vulgaris Margalef 1949.

Communites of filamentous and reticular algae.

Ass. Cladophoretum glomeratae Sauer 1937.

Ass. Hydrodictyetum reticulati Pignatti 1957.

Formations of Oedogonium capilliforme, Spirogyra spp., Pithophora oedogonia, Rhizodonium hieroglyphium. 